\title{
An improved rapid quantitative detection and identification method for a wide range of fungi
}

\begin{abstract}
Correspondence
Tatsuo Suzutani

suzutani@fmu.ac.jp
\end{abstract}

Received 23 September 2008

Accepted 4 May 2009

\author{
Nobutoshi Soeta, ${ }^{1} \dagger$ Masanori Terashima, ${ }^{1} \ddagger$ Mitsukazu Gotoh, ${ }^{1}$ \\ Shuichi Mori, ${ }^{2}$ Kyoko Nishiyama, ${ }^{2}$ Ken Ishioka, ${ }^{2}$ Hisatoshi Kaneko ${ }^{2}$ \\ and Tatsuo Suzutani ${ }^{2}$ \\ ${ }^{1}$ Department of Surgery I, Fukushima Medical University School of Medicine, 1 Hikarigaoka, \\ Fukushima 960-1295, Japan \\ ${ }^{2}$ Department of Microbiology, Fukushima Medical University School of Medicine, 1 Hikarigaoka, \\ Fukushima 960-1295, Japan
}

To develop a rapid and quantitative diagnostic technique for the detection and identification of a wide range of fungi, an improved molecular method based on real-time PCR and the analysis of its products that targets the internal transcribed spacer (ITS) 2 region was established. The real-time PCR could quantitatively and specifically detect the ITS2 region from all 24 tested pathogenic fungal species at between $10^{1}$ and $10^{7}$ copies per test without amplification of bacterial or human DNA. The sequences of the primer-binding sites are conserved in the registered sequences of 34 other pathogenic fungal species, suggesting that the PCR would also detect these species. The hyperpolymorphic nature of the ITS2 region between fungal species in terms of length and nucleotide sequence provided valuable information for the determination of species. By labelling the $5^{\prime}$ end of the reverse primer with NED fluorescent dye, the fragment lengths of the real-time PCR products and their $3^{\prime}$-terminal fragments, derived using restriction enzyme ScrFI digestion, were easily evaluated by capillary electrophoresis. Using this analysis, the number and species of fungi present in samples could be estimated. Moreover, sequence analysis of the real-time PCR products could accurately determine species in samples containing a single species. This diagnostic technique can estimate a wide range of fungi from various clinical samples within 1 day and accurately identify them in 2 days. Quantitative results for fungal titre in samples can also provide useful information for understanding the progression of disease and the efficacy of antifungal chemotherapy.

\section{INTRODUCTION}

In recent years, the incidence of invasive opportunistic fungal infections has been increasing due to increases in the number of immunocompromised patients (Warnock, 2007). The survival of these patients is closely correlated with early antifungal chemotherapy (Morrell et al., 2005). However, conventional diagnostic techniques for fungal infections, such as blood culture and biochemical tests, lack sufficient sensitivity and specificity, and require several days or even weeks to obtain results (Espinel-Ingroff et al., 1998; Goodrich et al., 1991; Wald et al., 1997). Therefore, many cases of fungal infection have been treated through

Abbreviations: ITS, internal transcribed spacer; T-RFLP, terminal restriction fragment length polymorphism.

tPresent address: Division of Surgery, Southen Tohoku Research Institute for Neuroscience, 7-115 Yatsuyamada, Koriyama 963-8563, Japan.

$\ddagger$ Present address: Division of Gastric Surgery, Shizuoka Cancer Center, 1007 Shimonagakubo, Nagaizumityou, Suntougun 411-8777, Japan. the empirical use of antifungal compounds, although relatively lower susceptibilities of some fungi to certain compounds have been observed, such as Trichosporon to amphotericin B, Candida glabrata, Candida krusei and Aspergillus to fluconazole, and Candida parapsilosis and Cryptococcus neoformans to micafungin.

To meet the need for more rapid and accurate species identification, methods based on PCR, such as random amplified polymorphic DNA (RAPD)-PCR, restriction fragment length polymorphism (RFLP) analysis, real-time PCR with species-specific probes, and sequence analysis of amplicons, have been developed (Esteve-Zarzoso et al., 1999; Kami et al., 2001; Löffler et al., 2000; Millon et al., 2002; Pryce et al., 2003) . In particular, the use of realtime PCR technology has provided not only rapid and accurate results, but also clinical markers for understanding the progression of diseases and the efficacy of antifungal therapy via the fungal titre in samples (Kami et al., 2001). 
In these studies, most of the improved PCR protocols employ universal primers that are designed for conserved regions, such as the $18 \mathrm{~S}, 5.8 \mathrm{~S}$ and $28 \mathrm{~S}$ rRNA genes, since an ever-increasing number of species of fungi have been associated with opportunistic infection (Chen et al., 2001; De Baere et al., 2002; Esteve-Zarzoso et al., 1999; Jordanides et al., 2005; Kurtzman \& Robnett, 1997; Löffler et al., 2000; Perfect \& Schell, 1996; Turenne et al., 1999; Velegraki et al., 1999). However, these methods have not been optimized to cover a wide range of fungal species or to differentiate species. Therefore, in this study we report an improved rapid diagnostic technique targeting a wide range of fungi that can determine the titre of the fungus, clarify whether the infection is caused by a single species or a mixed infection, and identify pathogens from clinical samples, even if those samples contain human DNA.

\section{METHODS}

Strains. The reference strains listed in Table 1 were obtained from the German Collection of Micro-organisms and Cell Cultures Biological Resource Centre (Braunschweig, Germany) and NITE Biological Resource Centre (Kisarazu, Japan). Yeasts were grown on a malt agar medium for $48 \mathrm{~h}$ at $25{ }^{\circ} \mathrm{C}$, and moulds were grown on a potato dextrose agar medium for up to 7 days at $30-35{ }^{\circ} \mathrm{C}$ in accordance with the supplier's instructions.

Nucleotide sequences of the internal transcribed spacer (ITS) 2 region from the reference strains were determined by a PCR-directed sequencing method. The target region was amplified with PCR using the primers $18 \mathrm{~S}-\mathrm{F}$ (forward primer; 5 '-GAACCTGCGGAAGGATCATTA-3') and 28S-R (reverse primer; 5'-TACTTGTTCGCTATCGGTCT-3'), which were located outside the universal fungal primers ITS86M-F and ITS4M-R (Fig. 1b). The sequencing reaction was carried out using the same primers, and sequences were analysed on an ABI PRISM 3100 genetic analyser (Applied Biosystems).

Table 1. Predicted and evaluated fragment length of PCR products from the 24 reference strains

\begin{tabular}{|c|c|c|c|c|c|c|c|c|c|}
\hline \multirow[t]{2}{*}{ No. } & \multirow[t]{2}{*}{ Organism } & \multirow[t]{2}{*}{ Ref. strain ${ }^{\star}$ (accession no.) } & \multicolumn{3}{|c|}{ GenBank $\dagger$} & \multicolumn{2}{|c|}{ Sequence $\ddagger$} & \multicolumn{2}{|c|}{ GENESCAN\$ } \\
\hline & & & $\begin{array}{c}\text { Accession } \\
\text { no. }\end{array}$ & $\begin{array}{l}\text { Length } \\
\text { of PCR } \\
\text { product } \\
\quad(b p)\end{array}$ & $\begin{array}{c}\text { Length } \\
\text { restricted } \\
\text { by } S c r F I \\
(\text { bp } \|\end{array}$ & $\begin{array}{l}\text { Length } \\
\text { of PCR } \\
\text { product } \\
\text { (bp) }\end{array}$ & $\begin{array}{l}\text { Length } \\
\text { restricted } \\
\text { by } S c r F I \\
(b p)\end{array}$ & $\begin{array}{c}\text { Length } \\
\text { of PCR } \\
\text { product } \\
\quad(b p)\end{array}$ & $\begin{array}{l}\text { Length } \\
\text { restricted by } \\
\text { ScrFI (bp) }\end{array}$ \\
\hline 1 & Candida albicans & DSM1386 (AB305093) & AY939789 & 297 & 297 & 297 & 297 & 297 & 297 \\
\hline 3 & Candida krusei & DSM6128 (AB305095) & AY939808 & 307 & 255 & 307 & 255 & 305 & 253 \\
\hline 4 & Candida parapsilosis & DSM5784 (AB305096) & AY217022 & 270 & 270 & 270 & 270 & 270 & 270 \\
\hline 5 & Candida famata & DSM70590 (AB305097) & AY125962 & 340 & 340 & 340 & 340 & 339 & 340 \\
\hline 6 & Candida guilliermondii & DSM11947 (AB305098) & AF218967 & 338 & 89 & 338 & 89 & 338 & 87 \\
\hline 7 & Candida tropicalis & DSM11953 (AB305099) & AY939810 & 287 & 192 & 287 & 192 & 287 & 190 \\
\hline 8 & Candida kefyr & NBRC0008 (AB480229) & AF218997 & 384 & 339 & 386 & 340 & 383 & 339 \\
\hline 13 & Trichosporon cutaneum & DSM70675 (AB305103) & AF444325 & 312 & 178 & 310 & 176 & 309 & 174 \\
\hline 14 & Trichosporon mucoides & DSM12017 (AB305104) & AF455482 & 308 & 174 & 310 & 176 & 309 & 174 \\
\hline 15 & Cryptococcus neoformans & DSM11959 (AB305105) & L14068 & 334 & 135 & 333 & 134 & 332 & 132 \\
\hline 16 & Rhodotorula mucilaginosa & DSM18184 (AB305106) & AF444635 & 363 & 113 & 363 & 113 & 363 & 110 \\
\hline 17 & Fusarium solani & DSM1164 (AB305107) & DQ486879 & 312 & 211 & 316 & 215 & 309 & 211 \\
\hline 18 & Mucor circinelloides & DSM1175 (AB305108) & AY243943 & 331 & 331 & 330 & 330 & 329 & 329 \\
\hline 19 & Rhizopus oryzae & DSM 853 (AB305109) & AY803931 & 335 & 107 & 335 & 107 & 336 & 104 \\
\hline 20 & Clavispora lusitaniae & NBRC1019 (AB480227) & $(-) \boldsymbol{9}$ & $(-)$ & $(-)$ & 211 & 125 & 211 & 124 \\
\hline 21 & Scedosporium apiospermum & NBRC31146 (AB480226) & AJ888399 & 338 & 111 & 339 & 111 & 332 & 103 \\
\hline 22 & Absidia corymbifera & DSM1144 (AB305110) & AY944897 & 425 & 425 & 424 & 424 & 424 & 424 \\
\hline 23 & Trichophyton rubrum & DSM4167 (AB305111) & AY213689 & 330 & 102 & 327 & 96 & 326 & 93 \\
\hline
\end{tabular}

${ }^{\star}$ Reference strains and accession numbers (in parentheses) for the sequences determined in this study.

$\dagger$ Predicted fragment length from the nucleotide sequence registered in GenBank.

$\ddagger$ Predicted fragment length from our sequencing results of the 24 reference strains.

§Fragment length of PCR products from the 24 reference strains as determined by GENESCAN analysis.

IITerminal fragment length of PCR products digested with the restriction enzyme ScrFI.

SData not registered in GenBank. 
(a)

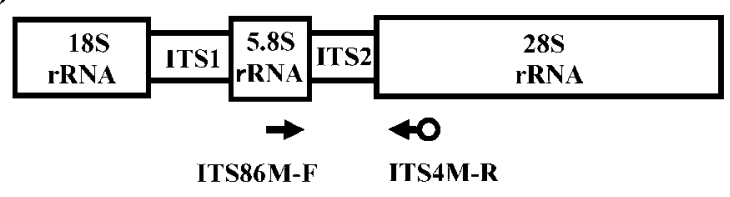

(b)

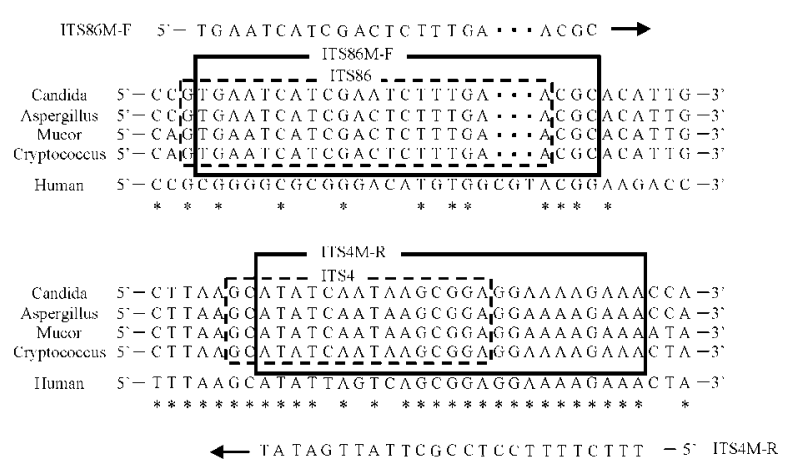

Fig. 1. Design of universal fungal primers. Location and direction of the newly designed primers (a) and comparison of the sequences of these primers with those of previously reported primers (b). Direction and position of primers ITS86M-F and ITS4M-R are shown by arrows and the NED-labelled $5^{\prime}$ end of ITS4M-R is shown by an open circle. The sequences of the primers designed in this study and those reported by Turenne et al. (1999) are enclosed with solid and dashed lines, respectively. Nucleotides identical to those observed in humans are marked with asterisks.

Extraction of fungal DNA. DNA was extracted from $500 \mu \mathrm{l}$ of whole EDTA-anticoagulated blood or fungal suspension in water by a previously described method with some modifications (Löffler et al., 1996). Briefly, after the addition of $3 \mathrm{ml}$ erythrocyte lysis buffer

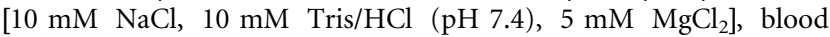
samples were incubated on ice for $10 \mathrm{~min}$, and then leukocytes and microbes were pelleted by centrifugation at 3000 r.p.m. $(800 \mathrm{~g})$ for 10 min with a low-speed centrifuge. The pellet was washed once with erythrocyte lysis buffer and resuspended in $450 \mu$ lyticase buffer [50 mM Tris/HCl (pH 7.5), $10 \mathrm{mM}$ EDTA, $0.2 \%$ 2-mercaptoethanol]. After sonication at full power for 3 min with an ELESTEIN035 ultrasonic homogenizer (Elekon, Tokyo, Japan), $50 \mu \mathrm{l}$ enzyme solution $\left[100 \mathrm{U} \mathrm{ml}^{-1}\right.$ of recombinant lyticase (Sigma-Aldrich) and $10 \mathrm{mg} \mathrm{ml}^{-1}$ of lysozyme chloride in lyticase buffer] was added to the samples. After incubation at $37{ }^{\circ} \mathrm{C}$ for $30 \mathrm{~min}$, the resultant spheroplasts were broken using an ultrasonic homogenizer for $5 \mathrm{~min}$ and DNA was spun down at 18000 r.p.m. (30000 $\mathrm{g}$ ) for 10 min with a microcentrifuge. DNA was purified from the pellet with a QIAmp DNA Mini kit (Qiagen) according to the manufacturer's instructions. The DNA recovered from $50 \mu$ l elution buffer was analysed immediately or stored at $-20{ }^{\circ} \mathrm{C}$ until testing.

Construction of DNA standards. The ITS2 region was amplified from Candida glabrata by PCR using the universal fungal primers ITS86M-F and ITS4M-R (Fig. 1b). The PCR products were then cloned into pGEM-T Easy Vector (Promega) using a TA cloning method. After confirming the nucleotide sequence of the insert, plasmid DNA (pGEM-CG-ITS2) was purified by a QIAprep Spin Miniprep kit (Qiagen) according to the manufacturer's instructions.
Real-time PCR assay. PCR was performed with $20 \mu \mathrm{l}$ of PCR mixture containing $0.2 \mu \mathrm{M}$ of each primer, ITS86M-F and ITS4M-R, $10 \mu \mathrm{l}$ SYBR Premix EX Taq (Takara Bio) and $2 \mu \mathrm{l}$ of sample DNA in an ABI PRISM 7000 Sequence Detection System (Applied Biosystems). For this PCR, we used tailed ITS86M-F, which consists of ITS86M-F with seven additional nucleotides at the $5^{\prime}$ end, as the forward primer and ITS4M-R, labelled with the fluorescent dye NED (Applied Biosystems) at the $5^{\prime}$ end for T-RLFP analysis (described below), as the reverse primer (Applied Biosystems). Initial denaturation was at $95{ }^{\circ} \mathrm{C}$ for $10 \mathrm{~s}$, followed by 35 cycles of denaturation at $95{ }^{\circ} \mathrm{C}$ for $5 \mathrm{~s}$, and annealing and extension at $66{ }^{\circ} \mathrm{C}$ for $31 \mathrm{~s}$. For each run, the standard curve was determined using 10 -fold diluted purified plasmid pGEM-CG-ITS2 at $10^{1}-10^{7}$ copies $\mu \mathrm{I}^{-1}$. The copy number of the genomic DNA in $1 \mu \mathrm{l}$ of sample was then determined from the standard curve with no account taken of the amount of human DNA present in the samples. The specificity of the PCR was analysed by melting curve analysis.

To determine the specificity of the primers ITS86M-F and ITS4M-R, PCR was carried out using DNA prepared from Candida glabrata, Staphylococcus aureus, Escherichia coli, and a human fibroblast cell line, hTART-BJ1 (BD Biosciences Clontech). Conditions for the realtime PCR for fungi using ITS86M-F and ITS4M-R are described above. A fragment of approximately $400 \mathrm{bp}$ from the human suppressor of cytokine signalling-3 (SOCS-3) gene was amplified using primers SOCS3-Nhe (5'-TAGCTAGCGGCGCACGGAGCCAGCGTGG-3') and SOCS3-400Kpn (5'-TATGGTACCCCAGGCAGTCCCGGGGGCCC-3'). Initial denaturation was at $95{ }^{\circ} \mathrm{C}$ for $2 \mathrm{~min}$, followed by 40 cycles of denaturation $\left(30 \mathrm{~s}\right.$ at $\left.95^{\circ} \mathrm{C}\right)$, annealing $\left(1 \mathrm{~min}\right.$ at $\left.58{ }^{\circ} \mathrm{C}\right)$ and extension $\left(30 \mathrm{~s}\right.$ at $\left.72{ }^{\circ} \mathrm{C}\right)$. Using the universal primers for the bacterial $16 \mathrm{~S}$ rRNA gene, 27f $\left(5^{\prime}\right.$ AGAGTTTGATCCTGGCTCAG- ${ }^{\prime}$ ) and 803r (5'-CATCGTTTACGGCGTGGAC-3'), a fragment of approximately $800 \mathrm{bp}$ from the bacterial gene was amplified under thermal cycling conditions as follows: initial denaturation $\left(95{ }^{\circ} \mathrm{C}\right.$ for $\left.2 \mathrm{~min}\right)$ and 40 cycles of denaturation $\left(30 \mathrm{~s}\right.$ at $\left.95{ }^{\circ} \mathrm{C}\right)$, annealing $\left(1 \mathrm{~min}\right.$ at $\left.56{ }^{\circ} \mathrm{C}\right)$ and extension $\left(1 \mathrm{~min}\right.$ at $\left.72{ }^{\circ} \mathrm{C}\right)$.

Fragment length analysis of PCR products. The DNA fragment lengths were determined to estimate the number and approximate the species of fungi present in the sample. One microlitre of the real-time PCR products, labelled with NED by the reverse primer, was treated with or without the restriction enzyme in $10 \mu \mathrm{l}$ of reaction mixture. Digestion was performed by incubating a $1 \mu \mathrm{l}$ aliquot of the PCR products with the restriction enzyme $S c r F I$ in a final reaction volume of $10 \mu \mathrm{l}$ at $37{ }^{\circ} \mathrm{C}$ for $1 \mathrm{~h}$. After digestion, $1 \mu \mathrm{l}$ of the reaction mixture was mixed with $10 \mu \mathrm{l}$ capillary electrophoresis mixture, consisting of $9.5 \mu \mathrm{l} \mathrm{Hi}$-Di formamide and 0.5 $\mu$ l GENESCAN 400HD (ROX) or 500 (LIZ) Size Standard (Applied Biosystems), and analysed with an ABI PRISM 3100 genetic analyser using GENESCAN analysis software version 3.7 (Applied Biosystems).

\section{RESULTS AND DISCUSSION}

\section{Design of universal fungal primers for real-time PCR}

Four regions, the 18S rRNA gene, ITS1 region, ITS2 region and $28 \mathrm{~S}$ rRNA gene (D1/D2 region), have been previously reported as potential targets for the development of a universal fungal PCR primer (Chen et al., 2000; Kurtzman \& Robnett, 1997; Lott et al., 1993; Makimura et al., 1994; Turenne et al., 1999). We aligned these regions from the human DNA sequence and various fungal DNA sequences 
derived from our original sequencing results and the GenBank database, and searched the regions with a consensus sequence for most fungal species but not the human sequence. From these regions, we chose two candidate sites, in the $5.8 \mathrm{~S}$ and $28 \mathrm{~S}$ rRNA genes, for the construction of a primer set for real-time PCR whereby the PCR products would be kept below $400 \mathrm{bp}$ through a limitation of the real-time PCR and at least one primer would be specific for fungi, so as to avoid amplification of any human DNA present in the clinical samples (Fig. 1a). The primer set designed for the regions had been reported as ITS86 and ITS4 (Turenne et al., 1999); however, we modified these primers to create ITS86M-F and ITS4M-R (Fig. 1b) with the following advantages; (i) the lengths of ITS86M-F and ITS4M-R were 2- and 8-mer longer than the original primers, respectively, leading to an increase in $T_{\mathrm{m}}$ and specificity, (ii) ITS86M-F was synthesized as a tailed primer consisting of a specific sequence for the fungal $5.8 \mathrm{~S}$ rRNA gene and seven additional nucleotides at the $5^{\prime}$ end to stimulate Taq polymerase for the generation of singlebase $3^{\prime}$ adenine overhangs and to produce PCR products of uniform length, and (iii) ITS4M-R was labelled with the fluorescent marker NED at the $5^{\prime}$ end for the detection of PCR products by capillary electrophoresis. These primers amplified a single PCR product from Candida glabrata but none from human or bacterial DNA, and were able to successfully amplify the ITS2 region from each of the 24 fungal reference strains.

\section{Sample preparation}

To increase the usefulness of our assay for practical diagnostic purposes, a reduction in time taken from sample collection to final diagnosis was also required. DNA extraction is generally a time-consuming and troublesome step, requiring more than half a working day (Löffler et al., 1996; Lugert et al., 2006). Therefore, we improved this step through the use of an ultrasonic homogenizer insread of proteinase treatment for disrupting fungi and established a rapid and quantitative DNA extraction method (see Methods).

\section{Sensitivity of real-time PCR}

The detection limit and quantification capacity of the realtime PCR assay for fungi with the primer set ITS86M-F/ ITS4M-R was evaluated using the Candida glabrata target region cloned into the pGEM-T plasmid as a template. The $100 \%$ detection limit of PCR was 10 copies per microlitre of the template (Fig. 2a). Melting curve analysis indicated that the reaction products were specific and a quantitative result was obtained from $10^{1}-10^{7}$ copies $\mu \mathrm{l}^{-1}$ (Fig. 2b, c). This PCR efficacy would be influenced by the amount of human DNA present in samples. It is impossible to adjust the amount of human DNA present in samples isolated from a variety of clinical specimens - blood, pus, cerebrospinal fluid and so on - giving rise to possible inaccuracies; however, the results of the continuous

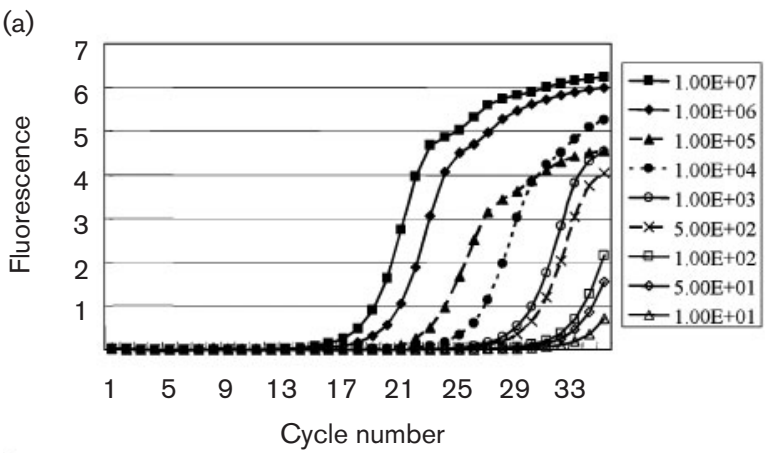

(b)
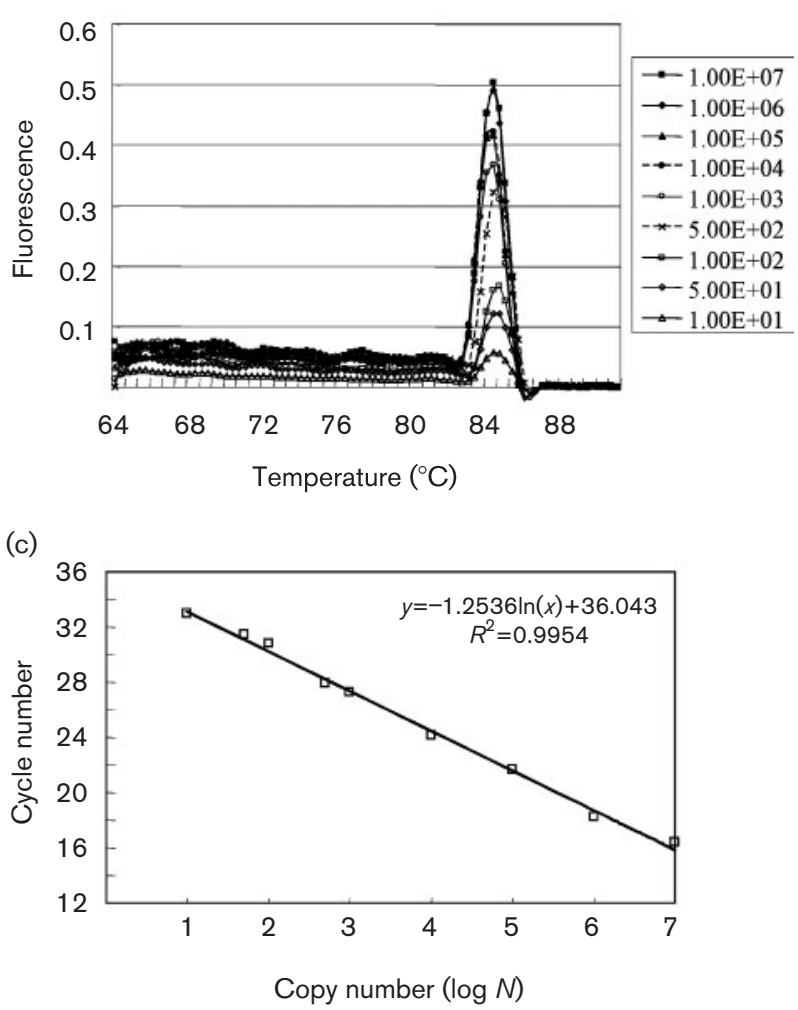

Fig. 2. Results of real-time PCR with control plasmid pGEM-CGITS2. Profile of PCR products (a), melting curve analysis (b) and standard curve (c). The plasmid, serially diluted from $10^{1}$ to $10^{7}$ copies per assay, was amplified and the amount of PCR product was monitored at the end of each cycle with SYBR Green. The slope of the standard curve was -1.2536 cycles per log decade and the correlation coefficient was 0.9954 .

monitoring of one patient and the existence of significant differences in log-order between corresponding specimens from different patients would nevertheless provide us with valuable information.

\section{Fragment length analysis of PCR products}

Data from the GenBank database and our sequencing results from the 24 fungal reference strains showed that 


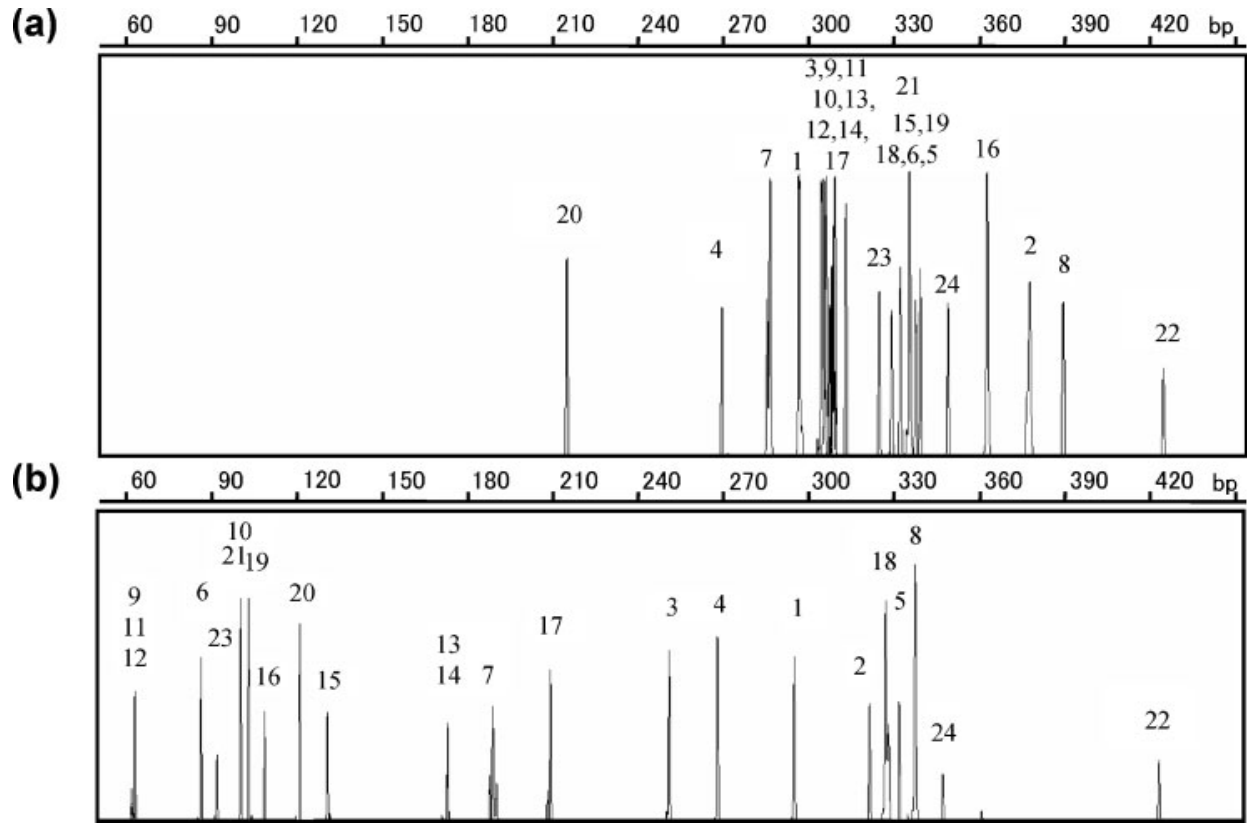

Fig. 3. Capillary electrophresis (GENESCAN) analysis of (a) PCR products from 24 reference strains and (b) T-RFLP for the 24 reference strains. In the T-RFLP analysis, PCR products were digested with the restriction enzyme ScrFl. Numbers from 1 to 24 indicate fungal species corresponding to those in Table 1.

PCR product length is highly variable among fungal species, ranging from $211 \mathrm{bp}$ for Clavispora lusitaniae to $424 \mathrm{bp}$ for Absidia corymbifera (Table 1), and that the sequences of the ITS2 region are hyper-variable between species, as described previously (Chen et al., 2001; Rakeman et al., 2005). Therefore, the length of amplicons or fragments after restriction enzyme digestion can provide valuable information regarding the number and identification of species in samples. For this purpose, we used a NED-labelled primer (ITS4M-R) as the reverse primer for real-time PCR and analysed the 3 ' terminal fragment length of PCR products from the 24 reference strains with and without restriction enzyme digestion (T-RLFP).

Of the 24 fungal species, nine (numbers 20, 4, 7, 1, 24, 16, 2, 8 and 22) could be differentiated from the other 15 without restriction enzyme digestion (Fig. 3a). Within the genus Candida (designated 1-8 in Fig. 3a; refer to Table 1), the ITS2 fragments ranged from 270 to $386 \mathrm{bp}$ in length. However, the product size from (i) Candida famata (5) and Candida gulliermondii (6), (ii) Cryptococcus neoformans (15), Rhizopus oryzae (19), Mucor circinelloides (18) and Scedosporium apiospermum (21), and (iii) Aspergillus spp. (9-12), Trichosporon spp. $(13,14)$, C. krusei (3) and Fusarium solani (17), were of similar lengths, ranging from 338 to 339 bp, 329 to $336 \mathrm{bp}$ and 305 to $312 \mathrm{bp}$, respectively.

To differentiate between these species, we selected ScrFI as the most suitable restriction enzyme and established a
T-RFLP analysis system. Using this method, the ITS2fragment lengths from each species ranged from $64 \mathrm{bp}$ for Aspergillus flavus (9) and Aspergillus niger (11) to 424 bp for Absidia corymbifera (22; Fig. 3b). Fourteen species from the 24 test fungal species were clearly differentiated (Table 1, Fig. 3).The lengths of PCR products and the $3^{\prime}$ terminal fragments obtained by ScrFI digestion for 34 other pathogenic fungal species predicted from sequence data in GenBank are summarized in Table 2.

We observed slight differences between the fragment lengths predicted from the sequence data and those evaluated by GENESCAN for Aspergillus and Trichosporon (Table 1). This discrepancy can be explained by the fact that electrophoretic migration is partially sequence dependent (Chen et al., 2001). Fragment length polymorphisms involving a few base pairs were also observed between strains registered in GenBank. These indicated that small interspecies differences in fragment length, which were observed in two groups of around $310 \mathrm{bp}$ and $340 \mathrm{bp}$, could not be used to differentiate fungi at the species level. We employed T-RFLP analysis in the assay using the restriction enzyme ScrFI and obtained adequate results for species identification. However, as we have not analysed the influence of polymorphisms in the nucleotide sequence in a large number of strains from one species, the effectiveness of T-RFLP analysis for the differentiation of strains has not yet been confirmed. 
Table 2. Predicted fragment length of PCR products from other less common species known to cause invasive fungal infection

Fragment lengths amplified by PCR using primers ITS86M-F and ITS4M-R were predicted from the registered sequences in GenBank. Asterisks signify no restriction enzyme site in the PCR product.

\begin{tabular}{|c|c|c|c|}
\hline Species & Accession no. & $\begin{array}{l}\text { Length of PCR } \\
\text { product (bp) }\end{array}$ & $\begin{array}{l}\text { Length restricted by } \\
\text { ScrFI (bp) }\end{array}$ \\
\hline Candida lipolytica & AF218983 & 196 & $196^{*}$ \\
\hline Candida lusitaniae & AF218970 & 211 & 125 \\
\hline Candida norvegensis & AY939799 & 280 & 235 \\
\hline Candida rugosa & AF218971 & 229 & $229^{*}$ \\
\hline Candida zeylanoides & AY382337 & 326 & $326^{*}$ \\
\hline Aspergillus nidulans & AY373888 & 305 & 103 \\
\hline Aspergillus restrictus & AY373864 & 309 & 68 \\
\hline Aspergillus versicolor & AY373883 & 304 & 100 \\
\hline Trichosporon asahii & AF444466 & 310 & $310^{*}$ \\
\hline Trichosporon asteroides & AF444416 & 310 & $310^{*}$ \\
\hline Trichosporon inkin & AF444420 & 310 & $310^{*}$ \\
\hline Trichosporon ovoides & AF444439 & 309 & $309^{*}$ \\
\hline Malassezia furfur & AY743635 & 509 & 238 \\
\hline Saccharomyces cerevisiae & AF219005 & 371 & 326 \\
\hline Geotrichum candidum & DQ907937 & 201 & $201^{*}$ \\
\hline Pneumocystis jerovecii & L27658 & 321 & $321^{*}$ \\
\hline Histoplasma capsulatum & AF038354 & 318 & 68 \\
\hline Paracoccidioides brasiliensis & AY631237 & 350 & 125 \\
\hline Alternaria alternata & AY714479 & 296 & $296^{*}$ \\
\hline Acremonium strictum & DQ297552 & 307 & 203 \\
\hline Cunninghamella bertholletiae & AF254931 & 357 & 226 \\
\hline Scedosporium prolificans & AY228120 & 321 & 105 \\
\hline Phialophora verrucosa & AF397136 & 318 & 82 \\
\hline Fonsecaea pedrosoi & AB087202 & 331 & 103 \\
\hline Cladosporium carrionii & AF397181 & 316 & 82 \\
\hline Exophiala dermatitidis & AY663828 & 349 & 123 \\
\hline Exophiala jeanselmei & DQ836795 & 320 & 91 \\
\hline Paecilomyces lilacinus & DQ641505 & 301 & 209 \\
\hline Paecilomyces variotii & AY373941 & 307 & 186 \\
\hline Fusarium oxysporum & DQ452455 & 289 & $289^{*}$ \\
\hline Penicillium marneffei & DQ399414 & 291 & 177 \\
\hline Blastomyces dermatitidis & AF038358 & 328 & 68 \\
\hline Sporothrix schenckii & AF484468 & 328 & 176 \\
\hline Pseudallescheria boydii & AY939802 & 338 & 108 \\
\hline
\end{tabular}

\section{Identification of species by nucleotide sequence analysis of PCR products}

It was previously reported that 372 of 373 tested fungal strains from 86 species $(99.7 \%)$ were correctly identified by sequence analysis of the ITS2 region. Only Cryptococcus albidus could not be differentiated from Cryptococcus adeliensis because of $100 \%$ sequence identity between the ITS2 regions of these two species (Leaw et al., 2006). We confirmed that the 24 strains tested in this study were correctly identified by sequence analysis of real-time PCR products (data not shown).

\section{Analysis of a clinical case}

To evaluate the efficacy of our method, serial whole-blood samples from a patient diagnosed with candidaemia due to central-venous catheter infection were analysed retrospectively (Fig. 4). The patient developed antibioticresistant fever and Candida albicans was isolated and identified from his blood sample on day 2 . Thus, antifungal chemotherapy with micafungin sodium $\left(100 \mathrm{mg}\right.$ day $\left.^{-1}\right)$ was started and Candida albicans was no longer detectable in blood sampled on day 8 or 15 . These three blood samples, which had been stored in a freezer, were examined using our real-time PCR system. Twenty-four copies of fungal DNA per microlitre were detected in the blood sample taken on day 2, but no fungal DNA was detected in the blood sampled on day 8 or 15 . The real-time PCR products from the sample taken on day 2 showed a single fluorescent peak corresponding to a product of $296 \mathrm{bp}$ both with and without ScrFI digestion. These results 


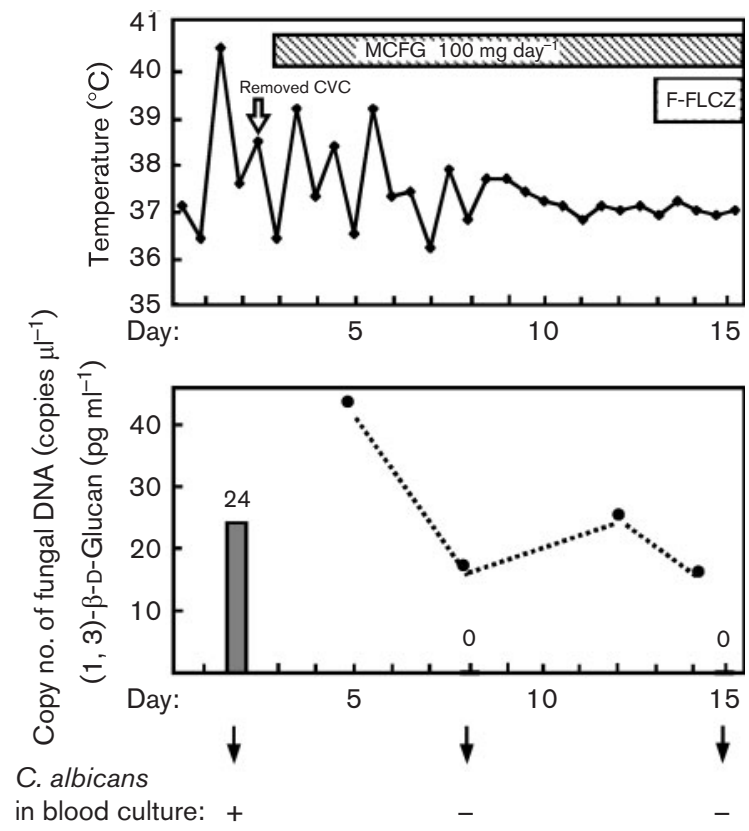

Fig. 4. Clinical course of a patient diagnosed with candidaemia due to central-venous catheter (CVC) infection. On day 2, Candida albicans was isolated from the blood culture. Retrospective analysis detected 24 copies $\mu^{-1}$ of fungal DNA in the blood. The CVC infection had cleared by day 3. After antifungal chemotherapy, no fungal DNA was detected in blood sampled on day 8 or 15 . Patient's temperature pattern; $\bullet$, patient's $(1,3)$ $\beta$-D-glucan pattern. The grey bar indicates the copy number of the fungal DNA. MCFG, micafungin; F-FLCZ, fosfluconazole (dose $400 \mathrm{mg}$ per day).

indicated that the patient was infected with one species and that it might be Candida albicans. By analysis of the nucleotide sequence of the amplicon, the pathogen was identified as Candida albicans, which corresponded to the results obtained from the blood culture.

\section{ACKNOWLEDGEMENTS}

This work was supported in part by a Grant-in Aid for Scientific Research from the Ministry of Education, Culture, Sports, Science and Technology, Japan (16590990 and 20591923) and a Grant-in-Aid for Project Research from Fukushima Medical University.

\section{REFERENCES}

Chen, Y.-C., Eisner, J. D., Kattar, M. M., Rassoulian-Barrett, S. L., Lafe, K., Yarfitz, S. L., Limaye, A. P. \& Cookson, B. T. (2000). Identification of medically important yeasts using PCR-based detection of DNA sequence polymorphisms in the internal transcribed spacer 2 region of the rRNA genes. J Clin Microbiol 38, 2302-2310.

Chen, Y.-C., Eisner, J. D., Kattar, M. M., Rassoulian-Barrett, S. L., Lafe, K., Bui, U., Limaye, A. P. \& Cookson, B. T. (2001). Polymorphic internal transcribed spacer region $1 \mathrm{DNA}$ sequences identify medically important yeasts. J Clin Microbiol 39, 4042-4051.
De Baere, T., Claeys, G., Swinne, D., Massonet, C., Verschraegen, G., Muylaert, A. \& Vaneechoutte, M. (2002). Identification of cultured isolates of clinically important yeast species using fluorescent fragment length analysis of the amplified internally transcribed rRNA spacer 2 region. BMC Microbiol 2, 21.

Espinel-Ingroff, A., Stockman, L., Roberts, G., Pincus, D., Pollack, J. \& Marler, J. (1998). Comparison of RapID yeast plus system with API 20C system for identification of common, new, and emerging yeast pathogens. J Clin Microbiol 36, 883-886.

Esteve-Zarzoso, B., Belloch, C., Uruburu, F. \& Querol, A. (1999). Identification of yeasts by RFLP analysis of the 5.8S rRNA gene and the two ribosomal internal transcribed spacers. Int J Syst Bacteriol 49, 329-337.

Goodrich, J. M., Reed, E. C., Mori, M., Fisher, L. D., Skerrett, S., Dandliker, P. S., Klis, B., Counts, G. W. \& Meyers, J. D. (1991). Clinical features and analysis of risk factors for invasive candidal infection after marrow transplantation. J Infect Dis 164, 731-740.

Jordanides, N. E., Allan, E. K., McLintock, L. A., Copland, M., Devaney, M., Stewart, K., Parker, A. N., Johnson, P. R. E., Holyoake, T. L. \& Jones, B. L. (2005). A prospective study of real-time panfungal PCR for the early diagnosis of invasive fungal infection in haematooncology patients. Bone Marrow Transplant 35, 389-395.

Kami, M., Fukui, T., Ogawa, S., Kazuyama, Y., Machida, U., Tanaka, Y., Kanda, Y., Kashima, T., Yamazaki, Y. \& other authors (2001). Use of real-time PCR on blood samples for diagnosis of invasive aspergillosis. Clin Infect Dis 33, 1504-1512.

Kurtzman, C. P. \& Robnett, C. J. (1997). Identification of clinically important ascomycetous yeasts based on nucleotide divergence in the $5^{\prime}$ end of the large-subunit (26S) ribosomal DNA gene. J Clin Microbiol 35, 1216-1223.

Leaw, S. N., Chang, H. C., Sun, H. F., Barton, R., Bouchara, J.-P. \& Chang, T. C. (2006). Identification of medically important yeast species by sequence analysis of the internal transcribed spacer regions. J Clin Microbiol 44, 693-699.

Löffler, J., Schumacher, U., Hebart, H., Reitze, H. \& Einsele, H. (1996). Extraction of fungal DNA from cultures and blood using the QIAamp Tissue Kit. Qiagen News 4, 16-17.

Löffler, J., Henke, N., Hebart, H., Schmidt, D., Hagmeyer, L., Schumacher, U. \& Einsele, H. (2000). Quantification of fungal DNA by using fluorescence resonance energy transfer and the light cycler system. J Clin Microbiol 38, 586-590.

Lott, T. J., Kuykendall, R. J. \& Reiss, E. (1993). Nucleotide sequence analysis of the 5.8S rDNA and adjacent ITS2 region of Candida albicans and related species. Yeast 9, 1199-1206.

Lugert, R., Schettler, C. \& Gross, U. (2006). Comparison of different protocols for DNA preparation and PCR for the detection of fungal pathogens in vitro. Mycoses 49, 298-304.

Makimura, K., Murayama, S. Y. \& Yamaguchi, H. (1994). Detection of a wide range of medically important fungi by the polymerase chain reaction. J Med Microbiol 40, 358-364.

Millon, L., Piarroux, R., Drobacheff, C., Monod, M., Grenouillet, F., Bulle, B., Bole, J., Blancard, A. \& Meillet, D. (2002). Evaluation of internal transcribed spacer region of ribosomal DNA sequence analysis for molecular characterization of Candida albicans and Candida dubliniensis isolates from HIV-infected patients. Med Mycol 40, 535-543.

Morrell, M., Fraser, V. J. \& Kollef, M. H. (2005). Delaying the empiric treatment of Candida bloodstream infection until positive blood culture results are obtained: a potential risk factor for hospital mortality. Antimicrob Agents Chemother 49, 3640-3645.

Perfect, J. R. \& Schell, W. A. (1996). The new fungal opportunists are coming. Clin Infect Dis 22, S112-S118. 
Pryce, T. M., Palladino, S., Kay, I. D. \& Coombs, G. W. (2003). Rapid identification of fungi by sequencing the ITS1 and ITS2 regions using an automated capillary electrophoresis system. Med Mycol 41, 369381.

Rakeman, J. L., Bui, U., Lafe, K., Chen, Y.-C., Honeycutt, R. J. \& Cookson, B. T. (2005). Multilocus DNA sequence comparisons rapidly identify pathogenic molds. J Clin Microbiol 43, 3324-3333.

Turenne, C. Y., Sanche, S. E., Hoban, D. J., Karlowsky, J. A. \& Kabani, A. M. (1999). Rapid identification of fungi by using the ITS2 genetic region and an automated fluorescent capillary electrophoresis system. J Clin Microbiol 37, 1846-1851.
Velegraki, A., Kambouris, M. E., Skiniotis, G., Savala, M., MitroussiaZiouva, A. \& Legakis, N. J. (1999). Identification of medically significant fungal genera by polymerase chain reaction followed by restriction enzyme analysis. FEMS Immunol Med Microbiol 23, 303-312.

Wald, A., Leisenring, W., Van Burik, J. A. \& Bowden, R. A. (1997). Epidemiology of Aspergillus infections in a large cohort of patients undergoing bone marrow transplantation. J Infect Dis 175, 14591466.

Warnock, D. W. (2007). Trends in the epidemiology of invasive fungal infections. Nippon Ishinkin Gakkai Zasshi 48, 1-12. 